\title{
Interleukin-1 Receptor Antagonist Decreases Bone Loss and Bone Resorption in Ovariectomized Rats
}

\author{
Robert B. Kimble, James L. Vannice, “ Duane C. Bloedow, " Robert C. Thompson, * Wendy Hopfer, \\ Viola T. Kung, ${ }^{\star}$ Cynthia Brownfield, and Roberto Pacifici \\ Division of Bone and Mineral Diseases, Washington University School of Medicine, and The Jewish Hospital of St. Louis, St. Louis, \\ Missouri 63110; * Synergen Inc., Boulder, Colorado 80301; and ${ }^{\ddagger}$ Metra Biosystems, Palo Alto, California 94304
}

\begin{abstract}
Interleukin-1 (IL-1), a cytokine produced by bone marrow cells and bone cells, has been implicated in the pathogenesis of postmenopausal osteoporosis because of its potent stimulatory effects on bone resorption in vitro and in vivo. To investigate whether IL-1 plays a direct causal role in post ovariectomy bone loss, 6-mo-old ovariectomized rats were treated with subcutaneous infusions of IL-1 receptor antagonist (IL-1 ra), a specific competitor of IL-1, for $4 \mathrm{wk}$, beginning either at the time of surgery or 4 wk after ovariectomy. The bone density of the distal femur was measured non invasively by dual-energy $X$-ray absorptiometry. Bone turnover was assessed by bone histomorphometry and by measuring serum osteocalcin, a marker of bone formation, and the urinary excretion of pyridinoline crosslinks, a marker of bone resorption. Ovariectomy caused a rapid increase in bone turnover and a marked decrease in bone density which were blocked by treatment with $17 \beta$ estradiol. Ovariectomy also increased the production of $I \mathrm{~L}-1$ from cultured bone marrow cells. Ovariectomy induced bone loss was significantly decreased by IL-1ra treatment started at the time of ovariectomy and completely blocked by IL-1ra treatment begun 4 wk after ovariectomy. In both studies IL-1ra also decreased bone resorption in a manner similar to estrogen, while it had no effect on bone formation. In contrast, treatment with IL-1ra had no effect on the bone density and the bone turnover of sham-operated rats, indicating that IL-1ra specifically blocked estrogen-dependent bone loss. In conclusion, these data indicate that IL-1, or mediators induced by IL-1, play an important causal role in the mechanism by which ovariectomy induces bone loss in rats, especially following the immediate post ovariectomy period. (J. Clin. Invest. 1994. 93:19591967.) Key words: interleukin-1 receptor antagonist • osteoporosis $\bullet$ cytokines $\bullet$ estrogen, interleukin-1
\end{abstract}

\section{Introduction}

Postmenopausal osteoporosis is a disorder characterized by a progressive loss of bone tissue which begins after natural or surgical menopause and leads to the occurrence of spontane-

Address correspondence to Dr. Roberto Pacifici, Division of Bone and Mineral Diseases, The Jewish Hospital of St. Louis, 216 S. Kingshighway, St. Louis, MO 63110.

Received for publication 21 June 1993 and in revised form 1 December 1993.

J. Clin. Invest.

(C) The American Society for Clinical Investigation, Inc.

0021-9738/94/05/1959/09 \$2.00

Volume 93, May 1994, 1959-1967 ous fractures (1). Although the causal role of estrogen deficiency in this condition is well established (2-4), the mechanism by which estrogen prevents bone loss is still conjectural at best. One such mechanism may be a modulatory effect on the secretion of factors that are produced in the bone microenvironment and influence bone remodeling (5). Among them is IL-1, a family of cytokines (6) best known for its involvement in inflammation and wound healing $(7,8)$, which is also recognized for its effects on bone remodeling. IL-1 stimulates bone resorption in vitro $(9,10)$ and in vivo $(11,12)$ and induces hypercalcemia when injected into normal mice (13) by stimulating the activity of mature osteoclasts (14) and the differentiation of osteoclast precursors (15). Studies have also shown that IL-1 inhibits bone formation in vitro (16) and in vivo (17) and induces bone cells to secrete several cytokines such as IL-6 (18), TNF $\alpha$ (15), and M-CSF (19), which regulate the proliferation of osteoclast precursor cells and their differentiation into active osteoclasts.

A role for IL-1 in postmenopausal bone loss is supported by recent studies showing that the expression of IL-1 mRNA is increased in bone cells from postmenopausal women (20) and by previous observations from us $(21,22)$ and others $(23,24)$ demonstrating that both natural and surgical menopause are associated with an increased production of IL-1 bioactivity from cultured monocytes that is blocked by estrogen replacement. However, the relevance of these findings with respect to the mechanism by which estrogen prevents bone loss has been difficult to elucidate, because estrogen regulates the production of several cytokines with overlapping effects on bone remodeling $(25,26)$.

Recently, a specific human IL-1 receptor antagonist (IL1 ra $)^{1}$ has been cloned and expressed in Escherichia coli with production of a recombinant $17-\mathrm{kD}$ protein which shares $26 \%$ sequence homology with IL-1 $\beta(27,28)$. IL-1 ra binds to IL-1 receptors and competes with both IL- $1 \alpha$ and IL- $1 \beta$ without detectable IL-1 agonistic effects $(29,30)$. Human IL-1 ra has provided a tool for blocking the effects of IL-1 in several rat cell types $(31,32)$ including bone cells (33) and to investigate the role of IL-1 in many diseases (34).

We have now assessed the effects of IL-1 ra on bone mineral density (BMD) and bone turnover in ovariectomized rats to investigate the role of IL-1 in the bone loss caused by estrogen deficiency.

\section{Methods}

Study protocol. Two experiments were conducted in 6-mo-old nulliparous rats (Harlan Sprague-Dawley, Inc., Madison, WI) subjected to

1. Abbreviations used in this paper: BMD, bone mineral density; IL$1 \mathrm{ra}, \mathrm{IL}-1$ receptor antagonist; TBV, trabecular bone volume. 
either dorsal ovariectomy or sham operation under general anesthesia. In each study ovariectomized animals were treated for 4 wk with continuous subcutaneous infusions of either IL-1 ra (Synergen Inc., Boulder, CO), IL-1 ra vehicle, BSA, or $10 \mu \mathrm{g} / \mathrm{kg}$ body wt per d $17 \beta$ estradiol. Sham-operated animals were treated for 4 wk with IL-1 ra, BSA, or control vehicle. In study 1 , treatments were started at the time of surgery. In this study ovariectomized rats were treated with either $0.4,2$, or $10 \mathrm{mg} / \mathrm{kg}$ body wt per d of IL-1 ra or $2 \mathrm{mg} / \mathrm{kg}$ body wt per d, BSA. Sham-operated rats were treated with $10 \mathrm{mg} / \mathrm{kg}$ body wt per d of IL-1 ra or $10 \mathrm{mg} / \mathrm{kg}$ body wt per d BSA. In study 2 , treatments were started 4 wk after surgery and the doses of IL-1 ra and BSA were $2.0 \mathrm{mg} / \mathrm{kg}$ body wt per $d$ for both the ovariectomized and the sham-operated rats. All treatments were delivered by implanting Alzet osmotic pumps (Alza Inc., Palo Alto, $C A$ ) in a dorsal subcutaneous pocket at time 0 and 2 wk of treatment. Alzet 2002 pumps were used to deliver IL-1 ra at the dose of 0.4 and $2.0 \mathrm{mg} / \mathrm{kg}$ body wt per d, BSA at $2.0 \mathrm{mg} / \mathrm{kg}$ body wt per d, $17 \beta$-estradiol, or IL-1 ra suspension vehicle. Alzet $2 \mathrm{ML} 2$ pumps were used to deliver IL- $1 \mathrm{ra}$ and BSA at $10 \mathrm{mg} / \mathrm{kg}$ body wt per $\mathrm{d}$. None of the rats exhibited evidence of infectious disease, impaired growth, immunosuppression, or other side effects caused by the IL-1 ra treatment. In a 10-d observation period preceding surgery, the ad lib. food consumption (regular rat Chow, Ralston Purina Co., St. Louis, MO) was $17 \mathrm{~g} / \mathrm{d}$. After surgery all rats were fed this amount of food in order to prevent unequal weight changes in the ovariectomized and sham-operated rats. Both at baseline and at the end of each study there were no differences in body weight between the ovariectomized and the sham-operated animals, nor between treatment groups (data not shown).

This protocol was approved by the Animal Care and Use Committee of the Jewish Hospital of St. Louis.

Bone density measurements. The BMD of the distal femur, an area rich in trabecular bone, was measured noninvasively in anesthetized rats by dual-energy X-ray absorptiometry (35) with a model QDR1000 densitometer (Hologic Inc., Waltham, MA) using a dedicated software for small animal measurements and a 2-mm collimator. This technique provides an integrated measure of both cortical and trabecular bone. In independent studies (35) the precision and the accuracy in vivo of this technique were determined by performing multiple measurements of the same rat and comparing BMD values with direct ash weight (cortical + trabecular bone) measurements of the femur. In these studies the precision and the accuracy in vivo of this technique were $1.2 \%$ and $89.0 \%$, respectively.

Bone histomorphometry. Quantitative bone histomorphometric analysis of the metaphysis of the distal femur and of the tibial diaphysis was carried out in specimens obtained at the end of experiment 2, according to the methods of Baron et al. (36) and Turner et al. (37), respectively. Specimens obtained from an additional group of untreated rats killed $4 \mathrm{wk}$ after ovariectomy were also analyzed. At 9 and 2 $\mathrm{d}$ before the rats were killed they were injected i.p. with $20 \mathrm{mg} / \mathrm{kg}$ body wt oxytetracycline hydrochloride (Pfizer Inc., Brooklyn, NY). The bone specimens were defleshed, fixed in Millonig's fixative, dehydrated in acetone, and embedded undecalcified in methyl methacrylate. Longitudinal sections ( $4 \mu \mathrm{m}$ thick) at a depth of one third to one half the thickness of each bone were prepared from the distal femur and stained with a modified Masson-Goldner trichrome. The region examined in the femur was that extending from 1.0 to $1.9 \mathrm{~mm}$ from the epiphyseal growth plate and $250 \mu \mathrm{m}$ from the endocortical surface. Trabecular bone volume (TBV), osteoclast surface (the percentage of bone surface covered by osteoclasts), osteoclast number per millimeter of bone surface, osteoid surface (the percentage of surface covered by osteoid), and osteoid thickness were measured in the stained sections. Dynamic (tetracycline-based) indices of bone formation were then measured on unstained sections as described (38).

For cortical bone analysis, cross sections $200 \mu \mathrm{m}$ thick were cut from the tibial diaphysis $15 \mathrm{~mm}$ from the proximal end using an Isomet low speed saw with a diamond wafer blade. The sections were ground to a thickness of 20-25 $\mu \mathrm{m}$ and mounted unstained on glass slides for analysis of the percent labeled endocortical and periosteal surfaces under ultraviolet light (38). Under transmitted light the same sections were used to quantify marrow area (the area within the endosteal surface of the specimen), cross-sectional bone area (the area within the periosteal surface of the specimen), cortical bone area (the area determined by subtracting marrow area from the cross-sectional area), and cortical thickness. All measurements were performed using a Bioquant Morphometry System (R\&M Biometrics, Inc., Nashville, TN).

Pyridinoline crosslinks assay. The urinary excretion of pyridinoline crosslinks, a marker of bone resorption $(39,40)$, was measured 2 and $4 \mathrm{wk}$ after surgery in urine samples collected between 2:00 and 6:00 p.m. using an ELISA kit developed by Metra Biosystems (Palo Alto, CA) (41). Briefly, a 10- $\mu$ l urine sample and $150 \mu$ l of rabbit antipyridinoline antiserum were added to a pyridinoline-coated microplate and incubated overnight. After the plates were washed with PBS, $150 \mu 1$ of goat anti-rabbit IgG alkaline phosphatase conjugate was added to each well. The unbound conjugate was then removed by washing and the enzyme activity measured photometrically by adding an enzyme substrate and using a microplate reader at $405 \mathrm{nM}$. Results were expressed as nanomoles per millimole of urinary creatinine, as measured by a standard colorimetric technique. The intra- and the interassay variation of this method are $<9 \%$ and $<15 \%$, respectively ( 42$)$.

Osteocalcin assay. Serum osteocalcin, a marker of bone formation (43), was measured 2 and 4 wk after surgery with a previously described radioimmunoassay method which makes use of an antibody highly specific for rat osteocalcin (44). The sensitivity of this assay is 10 $\mathrm{pg} / \mathrm{ml}$. All reagents were purchased from Biomedical Technologies Inc. (Stoughton, MA).

IL-1 ra assay. Serum levels of IL-1 ra were measured at 2 and 4 wk of treatment using a specific ELISA recently described (45). The sensitivity of this assay is $8 \mathrm{pg} / \mathrm{ml}$.

Cells cultures and IL-I assay. To investigate the effect of ovariectomy on the production of IL-1 from bone marrow cells, additional groups of untreated 6-mo-old rats were subjected to ovariectomy or sham operation as described above and killed 2 and $8 \mathrm{wk}$ after surgery. At sacrifice, femora were removed and dissected free of adherent tissue, the bone ends were cut across the ephiphyses and the bone marrow cavity flushed with RPMI 1640 tissue culture medium supplemented with $10 \mathrm{U} / \mathrm{ml}$ heparin and $1 \mu \mathrm{g} / \mathrm{ml}$ DNAase. The bone marrow was fractionated on Ficoll Hypaque to prepare mononuclear cell cultures as described $(21,22)$. The bone marrow mononuclear cells were seeded at $5 \times 10^{6}$ cells $/ \mathrm{ml}$ and cultured for $24 \mathrm{~h}$ with or without the addition of $100 \mathrm{pg} / \mathrm{ml}$ LPS. IL-1 bioactivity was measured in the 24-h culture media of the bone marrow mononuclear cells by assessing the increment in mitogen-induced proliferation of the helper T cell D10.G4.1 (D10 cells) as previously described $(21,22)$. D10 cell proliferation was converted to arbitrary units per milliliter of IL-1 activity by performing a log-logit transformation of the serial dilution curves and determining the dilution of the test sample that yielded a value corresponding to $50 \%$ of the standard IL-1 maximum activity. The standard IL-1 activity was arbitrarily set at $100 \mathrm{U} / \mathrm{ml}$. The nature of the assayed material was confirmed as IL-1 by demonstrating inhibition of the conditioned medium effect on the D10 cell proliferation in the presence of $50 \mathrm{ng} / \mathrm{ml}$ IL-1 ra.

Assessment of serum neutralization activity. The presence of biologically active IL-1 ra in the serum of IL-1 ra-treated rats was determined by assessing the serum obtained from ovariectomized rats at the end of the 4-wk-long IL-1 ra treatment against IL- $1 \beta$ augmentation of mitogen-induced proliferation of D10 cells. Rat sera ( $12.5 \mu \mathrm{l})$ or IL-1 ra (2.5 ng) were serially diluted (1:2) and added to D10 cells seeded in 96-well plates. Recombinant human IL-1 $\beta(7.5 \mathrm{pg})$ was then added to each well. This concentration of IL- $1 \beta$ was selected because it induces $50 \%$ maximal augmentation in the D10 cell proliferation assay. At the end of a 3-d culture period the D10 cell proliferation was measured as described above. Results were expressed as percent inhibition of D10 cell proliferation.

Statistical analysis. The effect of surgery and treatment on BMD was assessed by using analysis of variance for repeated measures. Subsequent multiple comparison tests were performed by using the Fisher protected LSD test. Group mean values were compared by two-tailed 
Table I. Effect of Ovariectomy and Sham Operation on the Secretion of IL-1 Bioactivity from Bone Marrow Mononuclear Cells

\begin{tabular}{|c|c|c|c|c|}
\hline & \multicolumn{2}{|c|}{$\begin{array}{c}2 \text { weeks } \\
\text { after surgery }\end{array}$} & \multicolumn{2}{|c|}{$\begin{array}{c}8 \text { weeks } \\
\text { after surgery }\end{array}$} \\
\hline & $\begin{array}{l}\text { Sham } \\
\text { operated } \\
(n=7)\end{array}$ & $\begin{array}{c}\text { Ovx } \\
(n=7)\end{array}$ & $\begin{array}{l}\text { Sham } \\
\text { operated } \\
(n=7)\end{array}$ & $\begin{array}{c}\text { Ovx } \\
(n=7)\end{array}$ \\
\hline & & & & \\
\hline $\begin{array}{l}\text { No LPS } \\
\text { No IL-1 ra }\end{array}$ & $2.3 \pm 0.4$ & $24.5 \pm 3.1^{*}$ & $3.2 \pm 0.3$ & $42.7 \pm 4.3^{*}$ \\
\hline $\begin{array}{l}\text { No LPS } \\
\text { IL-1 ra }(50 \mathrm{ng} / \mathrm{ml})\end{array}$ & $0.01 \pm 0.01^{\ddagger}$ & $0.01 \pm 0.01^{\ddagger}$ & $0.01 \pm 0.01^{\ddagger}$ & $0.01 \pm 0.01^{\ddagger}$ \\
\hline $\begin{array}{l}\text { LPS }(100 \mathrm{pg} / \mathrm{ml}) \\
\text { No IL-1 ra }\end{array}$ & $11.1 \pm 1.3$ & $68.0 \pm 10.5^{*}$ & $5.2 \pm 0.4$ & $93.5 \pm 10.4^{\S}$ \\
\hline $\begin{array}{l}\text { LPS }(100 \mathrm{pg} / \mathrm{ml}) \\
+\quad \mathrm{IL}-1 \mathrm{ra}(50 \mathrm{ng} / \mathrm{ml})\end{array}$ & $0.01 \pm 0.01^{\ddagger}$ & $0.01 \pm 0.01^{\ddagger}$ & $0.01 \pm 0.01^{\ddagger}$ & $0.01 \pm 0.01^{\ddagger}$ \\
\hline
\end{tabular}

6-mo-old untreated rats were subjected to either ovariectomy (Ovx) or sham operation. 2 or 8 weeks after surgery bone marrow mononuclear cells were isolated as described in Methods and cultured with and without LPS for $24 \mathrm{~h}$. IL-1 bioactivity was measured in the culture medium with the D10 cell bioassay with and without $50 \mathrm{ng} / \mathrm{ml}$ recombinant IL-1 ra, as described in Methods. The nature of the assayed material was confirmed as IL-1 by demonstrating inhibition of the conditioned medium effect on the D10 cell proliferation in the presence of recombinant IL-1 ra. Values are \pm SEM. ${ }^{*} P<0.05$ and ${ }^{\S} P<0.01$ compared to the corresponding group of sham-operated rats. ${ }^{\ddagger} P<0.01$ compared to all other groups.

Student's $t$ test, or one-way analysis of variance and Fisher protected LSD test, as appropriate.

\section{Results}

Ovariectomy increases the secretion of IL-1 from cultured bone marrow cells. Mononuclear cells cultured for $24 \mathrm{~h}$ in polystyrene plates with ordinary tissue culture media (which contains small amounts of LPS) express IL-1 mRNA and secrete small quantities of IL-1 $(46,47)$. In accordance with these published data, bone marrow cells from untreated sham-operated rats were found to secrete measurable amounts of IL-1 bioactivity into the 24-h culture medium (Table I). When further stimulated with the addition of $100 \mathrm{pg} / \mathrm{ml}$ LPS, bone marrow cells secreted higher amounts of IL-1 bioactivity which was neutralized by the addition of IL-1 ra to the assay system. 2 and $8 \mathrm{wk}$ after surgery bone marrow mononuclear cells from ovariectomized rats produced higher amounts of IL-1 bioactivity than the corresponding cells obtained from sham-operated animals rats (Table I).

Serum from IL-1ra-treated rats neutralizes IL-1B in vitro. IL-1 ra, as measured by a specific ELISA, was not detectable in the serum of rats treated either with vehicle or estrogen. In contrast, rats treated with $2 \mathrm{mg} / \mathrm{kg}$ body wt per d IL-1 ra had serum IL-1 ra levels of $160.6 \pm 8.6 \mathrm{ng} / \mathrm{ml}$ at 2 wk of treatment and $213.4 \pm 14.9 \mathrm{ng} / \mathrm{ml}$ at $4 \mathrm{wk}$. When tested in a proliferation neutralization assay, the serum of rats treated with IL-1 ra for 4 wk inhibited IL- $1 \beta$-induced augmentation of D10 cells proliferation in a manner similar to fresh recombinant IL-1 ra (Fig. 1). In these experiments parallel and dose-responsive inhibition curves of IL-1-induced augmentation of D10 cell proliferation were obtained with IL-1 ra and serum from IL-1 ra- treated rats. The sample dilution containing either $3 \mu \mathrm{l}$ of serum $(0.64 \mathrm{ng}$ of IL-1 ra by ELISA) or $0.5 \mathrm{ng}$ of fresh IL-1 ra per well inhibited about $50 \%$ of the IL- $1 \beta$-induced augmentation of proliferation.

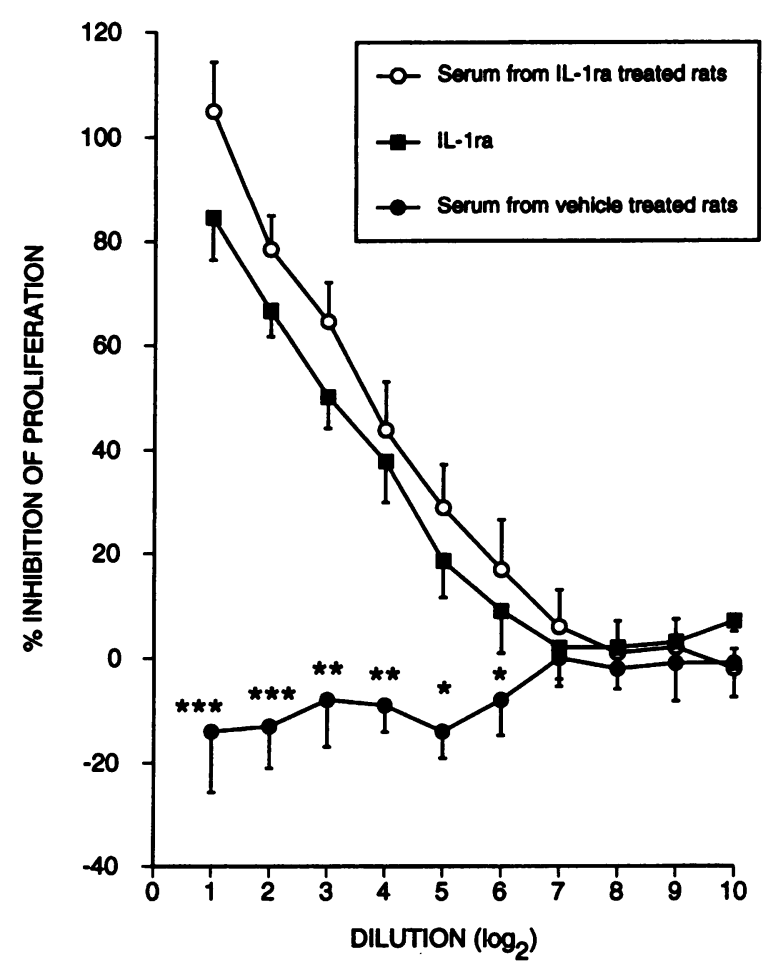

Figure 1. Effect of serum from IL-1 ra-treated rats on IL-1 $\beta$-induced augmentation of D10 cell proliferation (mean \pm SEM). Sera $(12.5 \mu \mathrm{l})$ obtained at the end of the treatment period from 14 ovariectomized rats treated with either IL-1 ra $(n=7)$ or vehicle $(n=7)$ or fresh IL$1 \mathrm{ra}(2.5 \mathrm{ng})(n=4)$ were serially diluted (1:2) and added to D10 cells seeded in triplicate in 96-well plates. Recombinant human IL- $1 \beta$ $(7.5 \mathrm{pg})$ was then added to each well. D10 cell proliferation was measured after a 3-d incubation, as described in Methods. Results (mean of three experiments) are expressed as percent inhibition of D10 cell proliferation. ${ }^{*} P<0.05,{ }^{* *} P<0.005$, and ${ }^{* * *} P<0.0001$ compared to the other two groups. 
These amounts of IL-1 ra were $\sim 85$ and 67 times the concentration of IL- $1 \beta$ used to stimulate the D10 cells, respectively. Serum from vehicle-treated rats had no effect on IL- $1 \beta$ induced augmentation of proliferation. These findings demonstrate that a 4-wk treatment with human IL-1 ra did not induce the formation of rat anti-human IL-1 ra antibodies in an amount capable of blocking the biological effects of IL-1 ra.

Effect of IL-1ra treatment on BMD. Fig. 2 shows the effect of IL-1 ra treatment on BMD in ovariectomized rats. During the treatment phase of study 1 (Fig. $2 A$ ) BMD decreased rapidly in BSA or vehicle-treated ovariectomized rats whereas no significant changes in BMD occurred in groups treated with $17 \beta$-estradiol. In this study rats were treated with three doses of IL-1 ra. The lowest dose of IL-1 ra $(0.4 \mathrm{mg} / \mathrm{kg}$ body wt per $\mathrm{d})$ was ineffective, as the changes in BMD in this group and in the control groups were similar. In contrast, 2 and $10 \mathrm{mg} / \mathrm{kg}$ body wt per $d$ of IL-1 ra were both effective, as the bone loss in these groups was lower $(P<0.05)$ than in either the vehicle or the BSA groups. Interestingly, the response to IL-1 ra was more pronounced in the second 2 wk of treatment than in the first 2 wk. In fact, the change in BMD between the second and the fourth week of IL-1 ra treatment was not significant.

In the pretreatment phase of study 2 (Fig. $2 B$ ) BMD decreased significantly in all groups of ovariectomized rats. During the treatment phase of this study BMD continued to decrease rapidly in rats treated with BSA or vehicle alone whereas no additional bone loss occurred in the estrogen-treated rats. In study 2, IL-1 ra completely arrested ovariectomy-induced bone loss. As a result, during the treatment period of this study there was no significant bone loss in either the IL-1 ra or the estrogen treated rats $(P<0.05$ compared to the vehicle or the BSA groups for both the estrogen and IL-1 ra groups) and the BMD values at the end of the study were similar in the IL-1 ra and the estrogen groups.

Table II shows the effect of IL-1 ra treatment in sham-operated animals. In each of the two studies a small, nonsignificant decrease in BMD was observed over time in all groups of shamoperated animals. These changes were similar in the vehicle, the BSA and the IL-1 ra groups, a finding indicating that IL-1 ra specifically prevents the bone loss associated with ovariectomy.

At the end of each study the weight of the uterus was lower in ovariectomized rats treated with vehicle or IL-1 ra than in ovariectomized rats treated with estrogen or sham-operated rats treated with either vehicle or IL-1 ra. In contrast, no difference in uterine weight was found between estrogen treated ovariectomized rats and sham-operated rats (data not shown). These findings demonstrate the efficacy of the ovariectomy and suggest that IL-1 ra has no estrogen-like effects.

Effect of IL-1 ra treatment on bone histomorphometry. In a preliminary study we determined that in rats of 6 mo of age, 8 wk are required for ovariectomy to induce a significant decrease in TBV, as assessed by histomorphometric analysis of distal femur metaphysis. For this reason, bone histomorphometry was used to analyze the effects of IL-1 ra on bone volume and bone turnover in the femur metaphysis and tibial diaphysis of rats treated between weeks 4 and 8 after surgery (experiment 2 ). Specimens from an additional group of untreated rats killed 4 wk after ovariectomy were also analyzed and used as additional (baseline) controls. Moreover, since bone densitometry showed that ovariectomy causes a similar bone loss in rats treated with vehicle and BSA, quantification of histomorphometric indices was not performed in rats treated with BSA.

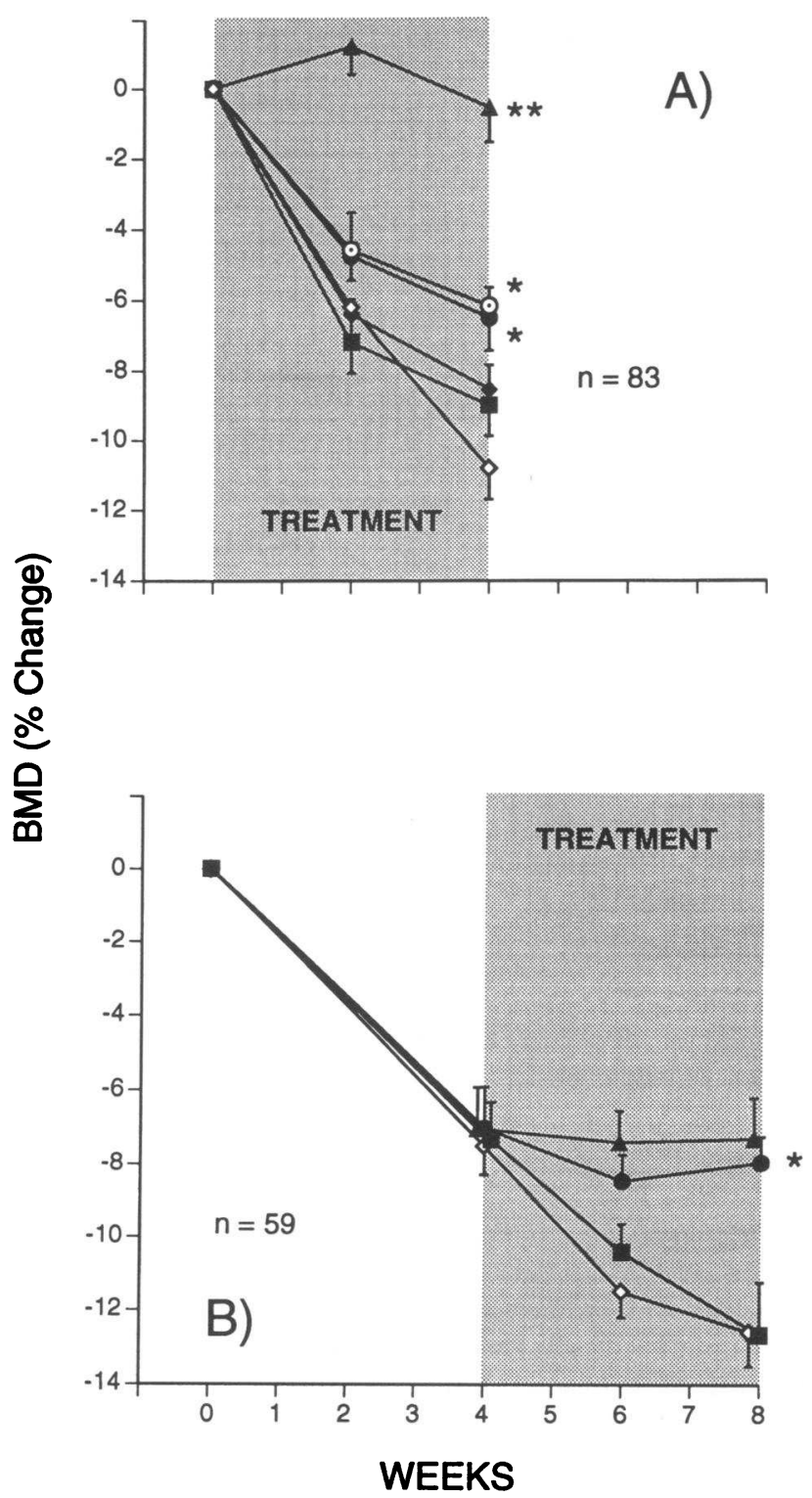

Figure 2. Effect of IL-1 ra treatment on distal femur BMD (mean \pm SEM). Results are expressed as percent change from baseline. In experiment 1 (panel $A$ ) treatments were started at the time of ovariectomy. In study 2 (panel $B$ ) treatments were started 4 wk after ovariectomy. Analysis by ANOVA for repeated measures and multiple range tests (Fisher protected LSD test) showed that at the end of each study ovariectomized rats treated with $2 \mathrm{mg} / \mathrm{kg}$ body wt per d IL-1 ra $(\bullet)(A$ and $B)$ or $10 \mathrm{mg} / \mathrm{kg}$ body wt per d IL-1 ra $(\odot)(A)$ had a smaller decrease $\left({ }^{*} P<0.05\right)$ in BMD than rats treated with IL-1 ra vehicle $(\bullet)$ or BSA $(\diamond)$, whereas those treated with $0.4 \mathrm{mg} /$ body wt per d IL-1 ra $(\bullet)(A)$ had not. At the end of study $1(A)$ the IL-1 ra and estrogen groups $(\triangle)$ were also significantly different $\left({ }^{* *} P\right.$ $<0.05)$. In study $2(B)$ there was no difference between the IL-1 ra and the estrogen group at both 2 and $4 \mathrm{wk}$ of treatment. Each treatment group consisted of a similar number of rats. Value $n$ represents the total number of rats which completed the corresponding experiment and which were subjected to BMD measurements at each time point. The baseline BMD values ( $100 \%$ ) were as follows: experiment 1: vehicle, $298 \pm 3.4 \mathrm{mg} / \mathrm{cm}^{2} ;$ BSA, $299 \pm 3.7 \mathrm{mg} / \mathrm{cm}^{2} ; 0.4 \mathrm{mg} /$ body wt per d IL-1 ra, $294.9 \pm 3.4 \mathrm{mg} / \mathrm{cm}^{2} ; 2 \mathrm{mg} / \mathrm{kg}$ body wt per d IL-1 ra, $293.1 \pm 3.1 \mathrm{mg} / \mathrm{cm}^{2} ; 10 \mathrm{mg} /$ body wt per d IL-1 ra, $298.5 \pm 3.4 \mathrm{mg} /$ $\mathrm{cm}^{2}$; estrogen, $296.6 \pm 3.4 \mathrm{mg} / \mathrm{cm}^{2}$. Experiment 2: vehicle, $300.3 \pm 3.0$ $\mathrm{mg} / \mathrm{cm}^{2}$; BSA, $299 \pm 3.2 \mathrm{mg} / \mathrm{cm}^{2} ; 2 \mathrm{mg} / \mathrm{kg}$ body wt per d IL- $1 \mathrm{ra}$, $297.9 \pm 2.4 \mathrm{mg} / \mathrm{cm}^{2}$; estrogen, $296.1 \pm 3.4 \mathrm{mg} / \mathrm{cm}^{2}$. 
Table II. Effect of IL-1ra Treatment on Distal Femur BMD (Percent Change from Baseline) in Sham-operated Rats

\begin{tabular}{|c|c|c|c|c|c|c|}
\hline \multirow[b]{2}{*}{ Group } & \multicolumn{3}{|c|}{$\begin{array}{l}\text { Study 1: treatment started at surgery } \\
\qquad(n=27)\end{array}$} & \multicolumn{3}{|c|}{$\begin{array}{l}\text { Study 2: treatment started } 4 \text { weeks after surgery } \\
\qquad(n=30)\end{array}$} \\
\hline & $\begin{array}{l}\text { BMD before } \\
\text { surgery }\end{array}$ & $\begin{array}{l}\text { BMD at } 2 \mathrm{wk} \\
\text { of treatment }\end{array}$ & $\begin{array}{l}\text { BMD at } 4 \mathrm{wk} \\
\text { of treatment }\end{array}$ & $\begin{array}{l}\text { BMD before } \\
\text { surgery }\end{array}$ & $\begin{array}{l}\text { BMD at } 2 \mathrm{wk} \\
\text { of treatment }\end{array}$ & $\begin{array}{l}\text { BMD at } 4 \mathrm{wk} \\
\text { of treatment }\end{array}$ \\
\hline & $\mathrm{mg} / \mathrm{cm}^{2}$ & \multicolumn{2}{|c|}{ \% change } & $\mathrm{mg} / \mathrm{cm}^{2}$ & \multicolumn{2}{|c|}{ \% change } \\
\hline BSA & $294.9 \pm 4.1$ & $-0.7 \pm 0.7$ & $-3.8 \pm 0.4$ & $301.1 \pm 3.7$ & $-2.3 \pm 0.9$ & $-2.6 \pm 0.8$ \\
\hline Vehicle & $295.8 \pm 4.5$ & $-1.7 \pm 1.3$ & $-3.4 \pm 0.8$ & $300.2 \pm 3.8$ & $-3.6 \pm 1.4$ & $-2.4 \pm 0.8$ \\
\hline IL-1 ra & $294.4 \pm 3.9$ & $-1.2 \pm 1.4$ & $-3.4 \pm 0.5$ & $297.7 \pm 4.4$ & $-3.6 \pm 0.5$ & $-3.6 \pm 0.5$ \\
\hline
\end{tabular}

Sham operation did not cause significant BMD changes in either of the two experiments. There were no significant differences between the vehicle-, and BSA-, and the IL-1 ra-treated sham-operated rats. All experimental procedures and statistical analysis were conducted as described in Fig. 2. In study 1 rats were treated with $10 \mathrm{mg} / \mathrm{kg}$ body wt per d IL-1 ra, $10 \mathrm{mg} / \mathrm{kg}$ body wt per d BSA, or IL-1 ra vehicle. In study 2 , rats were treated with $2 \mathrm{mg} /$ body wt per d IL-1 ra, $2 \mathrm{mg} / \mathrm{kg}$ body wt per d BSA or IL-1 ra vehicle. Values are \pm SEM.

During the second month after ovariectomy TBV decreased at a low rate in the vehicle-treated ovariectomized rats. As a result, the difference in TBV between baseline controls (killed at week 4 ) and the vehicle group (killed at week 8 ) slightly miss significancy $(P=0.058)$ (Fig. $3 A$ ). However, at week 8 the vehicle-treated ovariectomized rats had a lower TBV than both the vehicle and the IL-1 ra-treated sham rats. These findings indicate that ovariectomy induced a significant loss of trabecular bone and that a large part of this loss occurred in the first $4 \mathrm{wk}$ after ovariectomy. Estrogen was effective in preventing TBV loss during the treatment period, as indicated by the finding of a similar TBV in the estrogen-treated rats and the baseline control group. However, because of the small TBV loss in the vehicle group between weeks 4 and 8 , at the end of the study TBV was not significantly higher in the estrogen group than in the vehicle group. Treatment with IL-1 ra was also effective in preventing trabecular bone loss during the second month after ovariectomy, as demonstrated by the finding of a higher TBV in the IL-1 ra-treated group than in the baseline control group. Although this difference was not significant, as a result of the increase in TBV induced by IL-1 ra between weeks 4 and 8 , at the end of the study TBV was significantly higher in the IL-1 ra group than in the vehicle-treated rats. Taken all together, these data suggest that IL-1 ra was more potent than estrogen in preventing trabecular bone loss between weeks 4 and 8.

In vehicle-treated rats, ovariectomy was also associated with a significant increase in osteoclast number (Fig. $3 \mathrm{~B}$ ) and osteoclast covered surfaces (Fig. $3 C$ ). The lack of a difference between the vehicle group and the baseline controls indicate that bone resorption increased mainly during the first 4 wk after ovariectomy. The increase in these two indices of bone resorption was equally prevented by either IL-1 ra or estrogen. IL-1 ra had no effect on TBV and indices of bone resorption in sham-operated rats.

The effect of IL-1 ra on trabecular bone formation was evaluated by measuring static and dynamic (tetracycline-based) indices. Although metaphyseal endocortical surfaces showed an amount of double-labeled surfaces sufficient for precise quantification of dynamic indices of bone formation, $<0.5 \%$ of the metaphyseal trabecular surface utilized for the histomorphometric analysis exhibited double-tetracycline labeling, a finding consistent with a low rate of trabecular bone formation.
Although the small amount of double-labeled surfaces prevented a precise estimation of the rate of bone formation, the mineralized surface corresponded to the osteoid surface and estrogen, but not IL-1 ra or vehicle, appeared to decrease tetracycline-labeled trabecular surface (not shown). Analysis of static indices of bone formation showed that in sham-operated rats the amount of osteoid surface and the osteoid thickness were small (Table III) in both the vehicle and IL-1 ra treated rats. These findings are similar to those of Wronski et al. (48) and confirm that in aged rats bone formation takes place at a low rate. Although both indices increased slightly after ovariectomy, the differences were not significant. Moreover, neither IL-1 ra nor estrogen treatment induced significant changes in these indices.

Analysis of cortical bone ( Table IV) by histomorphometry of tibial diaphysis harvested at week 8 revealed that ovariectomy had no significant effects on cortical bone area, cortical thickness, marrow area, and cross-sectional area. Moreover, although the finding of a small amount of double-labeled surfaces prevented us from accurately measuring endosteal and periosteal bone formation rate, there was sufficient single labeling to accurately measure the percentage of labeled surface, a dynamic index of bone formation. We found that ovariectomy caused a significant increase in endosteal and periosteal labeled surfaces. Estrogen treatment between weeks 4 and 8 had no effect on static indices of bone and marrow areas. However, estrogen treatment induced a significant decrease in periosteal but not endosteal labeled surfaces. In contrast, IL-1 ra had no effect on both static and dynamic indices.

Effect of IL-1 ra treatment on urinary excretion of pyridinoline crosslinks and blood osteocalcin levels. Bone turnover is known to increase rapidly in response to estrogen withdrawal in both humans and rats (43). Therefore, in order to investigate the effects of IL-1 ra on the early changes in bone turnover induced by ovariectomy, the urinary excretion of pyridinoline crosslinks, a marker of bone resorption $(39,40)$, and the serum levels of osteocalcin, a marker of bone formation (43), were measured 2 and 4 wk after ovariectomy. At 2 wk after surgery, pyridinoline crosslink excretion and serum osteocalcin were both significantly higher in ovariectomized rats treated with vehicle than in sham-operated rats (Figs. 4 and 5). At 4 wk both indices were higher $(P<0.05)$ than at $2 \mathrm{wk}$, indicating that bone turnover continued to increase during the first 

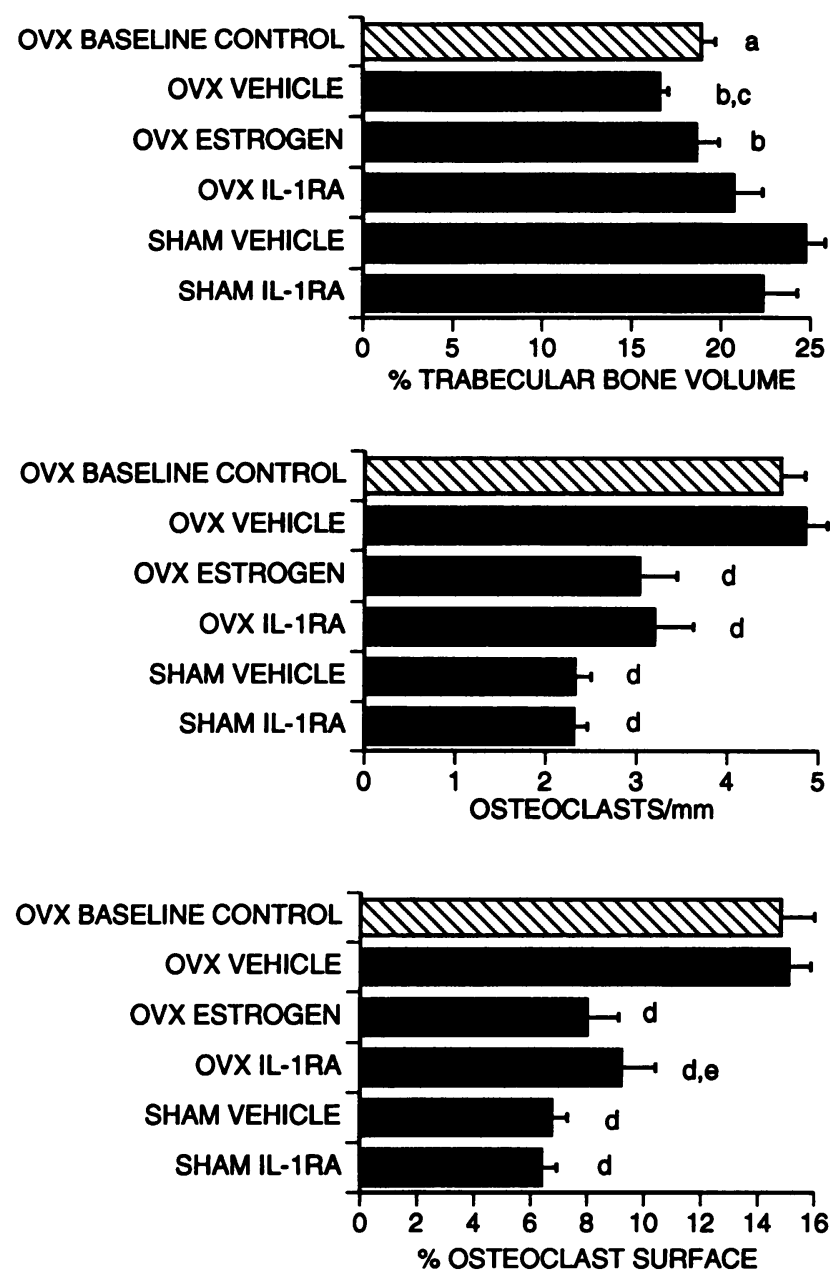

Figure 3. Effect of IL-1 ra treatment (mean \pm SEM) on TBV and histomorphometric indices of bone resorption. Rats treated with either vehicle, IL-1 ra or estrogen ( $n=10$ rats per group, randomly selected from the entire experimental group) between weeks 4 and 8 (study 2 ) were killed at the end of week 8 ( solid bars) and compared to untreated rats $(n=6)$ killed 4 wk after ovariectomy (baseline controls; hatched bars). Distal femurs were harvested and processed as described in the methods. Percent trabecular bone volume is the percentage of marrow space occupied by trabecular bone. Osteoclasts are given as the number of osteoclasts per millimeter of trabecular bone surface. Percent osteoclast surface is the percentage of trabecular surface containing osteoclasts with "resorptive bays." a $P<0.05$ compared to sham vehicle; ${ }^{b} P<0.05$ compared to sham vehicle and sham IL-1 ra; ${ }^{\mathrm{c}} P<0.05$ compared to ovx IL-1 ra; ${ }^{\mathrm{d}} P<0.05$ compared to ovx baseline and ovx vehicle; ${ }^{e} P<0.05$ compared to sham IL-1 ra by Fisher protected LSD test. month after ovariectomy. Treatment with IL-1 ra started at the time of surgery decreased pyridinoline excretion in ovariectomized rats (Fig. 4). At both 2 and 4 wk after ovariectomy pyridinoline excretion was, in fact, lower in rats treated with either IL-1 ra or estrogen than in those treated with vehicle. At 2 wk there was no difference between the IL-1 ra and the estrogen-treated rats. At $4 \mathrm{wk}$, a time point when bone resorption was higher, pyridinoline excretion was lower in the estrogen than in the IL-1 ra-treated ovariectomized rats. In sham-operated rats IL-1 ra treatment had no significant effects on pyridinoline excretion at both 2 and 4 wk.

The increase in serum osteocalcin induced by ovariectomy was prevented by estrogen treatment, but not by IL-1 ra treatment. In ovariectomized rats at both 2 and 4 wk osteocalcin levels were, in fact, significantly lower in the estrogen-treated rats than in either the IL-1 ra or the vehicle group. In addition, IL-1 ra treatment had no effect on osteocalcin levels in shamoperated rats.

\section{Discussion}

In this study we have found that treatment of ovariectomized rats with IL-1 ra decreases bone resorption and blocks ovariectomy-induced bone loss.

At the doses used in this study IL-1 ra competes specifically with IL-1 and does not possess IL-1 agonistic effects (49). In fact, infusions of IL-1 ra up to $80 \mathrm{mg} / \mathrm{kg}$ body wt per $\mathrm{d}$ to healthy humans have been shown to cause no detectable biological effects (50). The subcutaneous infusion of IL-1 ra resulted in serum IL-1 ra levels $\sim 10$ times higher than those required to block ${ }^{45} \mathrm{Ca}$ release in vitro from rat bone stimulated with 10 $\mathrm{ng} / \mathrm{ml}$ of IL-1 (33). Although there is no published information on either the amount of IL-1 released in vivo after ovariectomy or the level of IL-1 receptors expressed in rat bone cells, the need for such a high concentration of IL-1 ra to affect bone loss in vivo is not surprising, as it is known that biological responses to IL-1 can be observed when $\leq 5 \%$ of IL-1 receptors are occupied by IL-1 $(30,49)$. Interestingly, the anti-IL-1 activity of sera from rats treated with IL-1 ra for $4 \mathrm{wk}$ was similar to that of fresh IL-1 ra. This indicates that the 4-wk-long infusion did not result in the production of rat anti-human IL-1 ra antibodies in amounts sufficient to block the biological activity of IL-1 ra or that IL-1 ra treatment induced the formation of nonblocking antibodies.

The effects of IL-1 ra on TBV and bone density were evaluated by bone histomorphometry and by dual-energy X-ray absorptiometry, a noninvasive technique which provides precise integrated measures of cortical and trabecular bone (35). These measures were carried out in the distal femur, a weight bearing skeleton segment rich in trabecular bone. In agreement

Table III. Effect of IL-Ira on Histomorphometric Indices of Trabecular Bone Formation

\begin{tabular}{|c|c|c|c|c|c|}
\hline Parameter & $\begin{array}{l}\text { Sham vehicle } \\
\quad(n=10)\end{array}$ & $\begin{array}{l}\text { Sham IL-1 ra } \\
\quad(n=10)\end{array}$ & $\begin{array}{l}\text { Ovx vehicle } \\
\quad(n=10)\end{array}$ & $\begin{array}{l}\text { Ovx IL-1 ra } \\
(n=10)\end{array}$ & $\begin{array}{l}\text { Ovx estrogen } \\
\quad(n=10)\end{array}$ \\
\hline Percent osteoid surface* & $0.56 \pm 0.19$ & $0.64 \pm 0.23$ & $1.16 \pm 0.39$ & $0.41 \pm 0.23$ & $0.52 \pm 0.20$ \\
\hline Osteoid thickness ${ }^{\ddagger}(\mu m)$ & $1.15 \pm 0.33$ & $1.07 \pm 0.32$ & $1.33 \pm 0.31$ & $1.35 \pm 0.39$ & $1.22 \pm 0.33$ \\
\hline
\end{tabular}

Mean \pm SEM. * Percentage of trabecular surface covered by osteoid. ${ }^{\ddagger}$ Average osteoid width. 
Table IV. Effect of IL-Ira on Cortical Bone

\begin{tabular}{|c|c|c|c|c|c|c|}
\hline Group & Marrow area & $\begin{array}{l}\text { Cross-sectional } \\
\text { area }\end{array}$ & $\begin{array}{l}\text { Cortical bone } \\
\text { area }\end{array}$ & $\begin{array}{l}\text { Cortical } \\
\text { thickness }\end{array}$ & $\begin{array}{l}\text { Endosteal } \\
\text { labeled } \\
\text { surface }\end{array}$ & $\begin{array}{l}\text { Periosteal } \\
\text { labeled } \\
\text { surface }\end{array}$ \\
\hline & $m m^{2}$ & $m m^{2}$ & $m m^{2}$ & $m m$ & $\%$ & $\%$ \\
\hline Sham IL-1 ra & $2.45 \pm 0.18$ & $7.13 \pm 0.24$ & $4.67 \pm 0.09$ & $0.52 \pm 0.01$ & $0.60 \pm 0.37$ & $0.42 \pm 0.12$ \\
\hline Sham vehicle & $2.56 \pm 0.09$ & $7.23 \pm 0.17$ & $4.66 \pm 0.10$ & $0.51 \pm 0.01$ & $1.09 \pm 0.44$ & $0.74 \pm 0.24$ \\
\hline Ovx vehicle & $2.50 \pm 0.15$ & $7.21 \pm 0.23$ & $4.66 \pm 0.15$ & $0.51 \pm 0.01$ & $4.50 \pm 1.22^{a}$ & $15.8 \pm 1.99^{b}$ \\
\hline Ovx E2 & $2.18 \pm 0.14$ & $6.83 \pm 0.37$ & $4.65 \pm 0.24$ & $0.53 \pm 0.02$ & $2.55 \pm 0.83$ & $1.69 \pm 0.73$ \\
\hline Ovx IL-1 ra & $2.57 \pm 0.20$ & $7.25 \pm 0.29$ & $4.67 \pm 0.10$ & $0.51 \pm 0.01$ & $5.57 \pm 0.69^{a}$ & $14.4 \pm 2.84^{b}$ \\
\hline
\end{tabular}

Values are mean \pm SEM. $n=6$ rats per group. ${ }^{a} P<0.05$ compared to sham vehicle and sham IL-1 ra. ${ }^{b} P<0.05$ compared to sham vehicle, sham IL-1 ra, and ovariectomized (Ovx) estrogen (E2).

with earlier studies (51-53), both methods showed that ovariectomy causes a marked bone loss. However, because of the lower variability, a shorter follow-up was required to detect a significant bone loss with dual-energy X-ray absorptiometry than with bone histomorphometry. Our findings are consistent with those of earlier studies demonstrating both the higher sensitivity for bone mass quantification and the higher correlation with density measurements by physical means, of X-ray absorptiometry than bone histomorphometry $(54,55)$.

The bone-sparing effect of IL-1 ra was more potent in the second than in the first month after ovariectomy, a time when
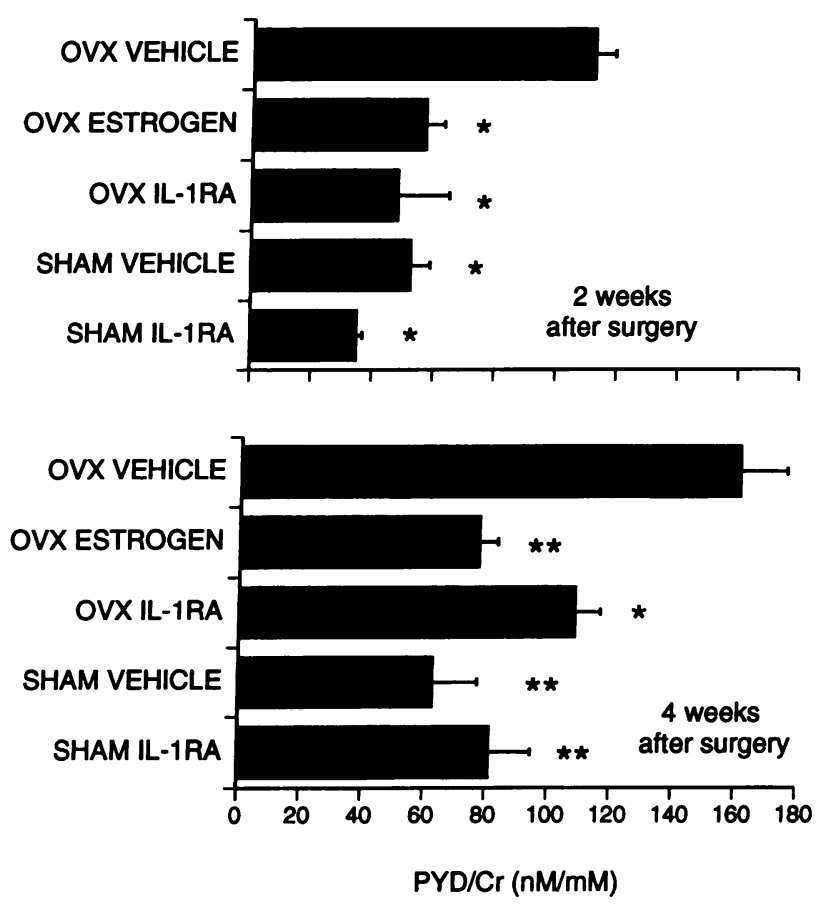

Figure 4. Effect of IL-1 ra treatment on the urinary excretion (mean \pm SEM) of pyridinoline crosslinks ( $n=8$ rats per group, randomly selected from the entire experimental group). The pyridinoline crosslinks/creatinine ratio ( $\mathrm{PYD} / \mathrm{Cr}$ ) was determined in urine samples collected 2 and 4 wk after surgery as described in Methods. Rats were treated with IL-1 ra during the first $4 \mathrm{wk}$ after surgery. ${ }^{*} P<0.05$ compared to vehicle treated ovariectomized rats. ${ }^{* *} P<0.05$ compared to both vehicle- and IL-1 ra-treated ovariectomized rats, by Fisher protected LSD test. bone marrow cell production of IL-1 bioactivity was the highest. In fact, bone loss was decreased, but not completely arrested, when rats were treated with IL-1 ra in the early postovariectomy period. In contrast, bone loss was completely arrested when rats were treated with IL-1 ra during the second month after ovariectomy. These data suggest that the role of IL- 1 in conditioning the changes in bone remodeling induced by estrogen deficiency increases with the passage of time since ovariectomy. This hypothesis is further supported by the finding that in each study IL-1 ra was also more effective during the second 2 wk than in the first 2 wk of treatment. In study 1 , the bone sparing effects of IL-1 ra at 2 or $10 \mathrm{mg} / \mathrm{kg}$ body wk per d were similar. An insufficient block of IL-1 activity is, therefore,
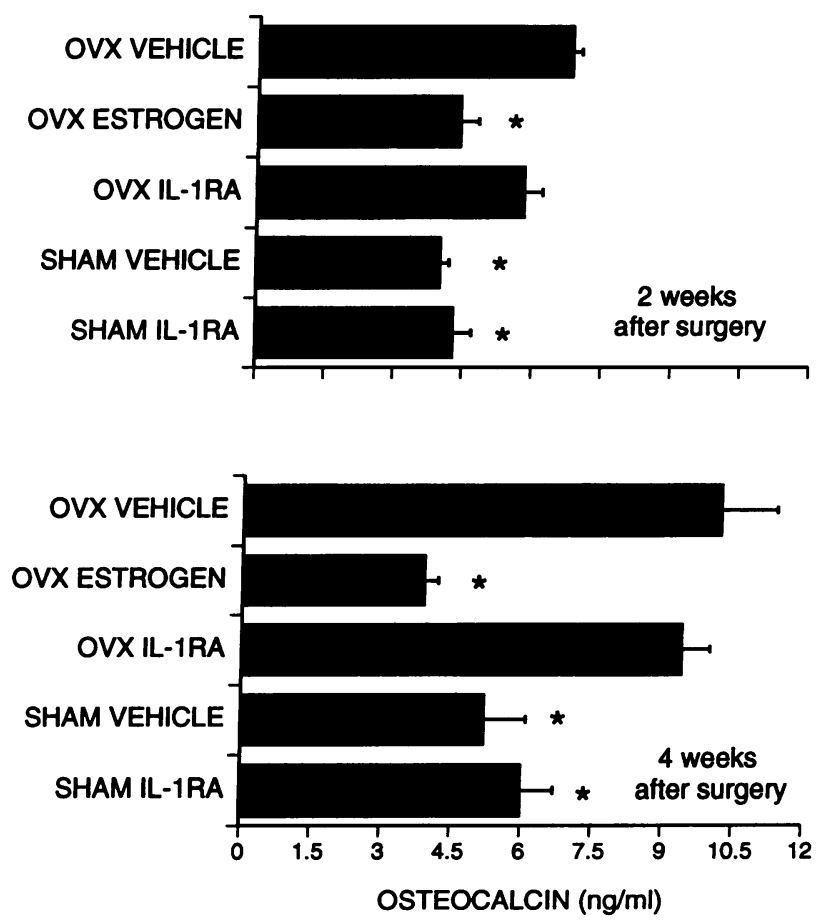

Figure 5. Effect of IL-1 ra treatment on the serum levels (mean \pm SEM) of osteocalcin ( $n=8$ rats per group, randomly selected from the entire experimental group). Osteocalcin was measured in serum samples collected 2 and 4 wk after surgery from rats treated with IL-1 ra during the first 4 weeks after surgery. ${ }^{*} P<0.05$ compared to both vehicleand IL-1 ra-treated ovariectomized rats by Fisher protected LSD test. 
an unlikely explanation for the inability of IL-1 ra to completely block bone loss in the early postovariectomy period.

To investigate the mechanism of the bone-sparing effect of IL-1 ra we have examined histomorphometric and biochemical indices of bone turnover. During the second month after ovariectomy IL-1 ra treatment resulted in a slight increase in TBV. In contrast, estrogen blocked, but did not reverse, trabecular bone loss. Interestingly, neither IL-1 ra nor estrogen affected cortical bone area. These data suggest that at week 8 the IL-1 raand the estrogen-treated rats had similar BMD values because the difference in trabecular bone density was too small to be detected by our densitometric technique, a method which is heavily influenced by cortical bone and provides an integrated measure of the density of the two skeleton envelopes.

Although we were unable to accurately quantitate trabecular bone formation, analysis of cortical bone by bone histomorphometry and of serum osteocalcin levels indicated that estrogen, but not IL-1 ra, prevented the increase in indices of bone formation which typically follows ovariectomy in rats $(37,56)$. We recognize that the different effects of the two agents on bone formation should be interpreted with caution. However, one may speculate that estrogen modulates bone resorption via an IL-1-dependent pathway and bone formation via a distinct, IL-1-independent, mechanism.

Our findings also demonstrate that IL-1 ra decreases bone resorption in a manner similar to estrogen replacement. Interestingly, the effect of IL-1 ra on pyridinoline crosslink excretion during the first month after ovariectomy was more potent than that observed in the same time period with BMD measurements. This is consistent with previous human studies demonstrating that biochemical markers of bone turnover do not faithfully reflect the rate of bone loss at the time of the marker measurement, but rather correlate moderately with BMD measurements (43).

IL-1 ra had no effect on the bone density and on the bone turnover of sham-operated rats, indicating that IL-1 ra specifically blocks estrogen-dependent bone loss. The data are also consistent with the lack of published evidence for a role of IL-1 in physiologic bone remodeling.

Taken all together, our findings demonstrate that IL-1 contributes to the pathogenesis of postovariectomy bone loss. However, the incomplete response to IL-1 ra observed in the early postovariectomy period suggests that other factors may contribute to the bone loss induced by estrogen withdrawal. A likely candidate is IL-6. This cytokine is, at least in the mouse, regulated by estrogen (26), and an increased production of IL-6 in the bone marrow of ovariectomized mice increases osteoclastogenesis in vitro (18). Thus, since the secretion of IL-6 from stromal cells and bone cells is induced by both IL-1 and TNF $\alpha$ (26), our findings could, indeed, be explained by a persistent production of IL-6. Conversely, the similar response to estrogen and IL-1 ra in the second month after ovariectomy, suggests that the production of, or the response to, IL- 6 or other cytokines produced independently of IL-1 may decrease in the late postovariectomy period.

In conclusion, the present findings indicate that IL-1, or mediators induced by IL-1, play an important causal role in the mechanism by which ovariectomy induces bone loss in rats, especially following the early postovariectomy period. It will be interesting, therefore, to investigate whether IL-1 ra has a practical role in the treatment of postmenopausal osteoporosis in humans.

\section{Acknowledgments}

This study was supported by grants from the National Institutes of Health (AR 39706 and AR 41412) and by Synergen Inc.

\section{References}

1. Anonymous Consensus Conference: Osteoporosis. 1984. J. Am. Med. Assoc. 252:799-802.

2. Riggs, B. L., and L. J. Melton. 1986. Medical progress: involutional osteoporosis. N. Engl. J. Med. 314:1676-1684.

3. Slemenda, C., S. L. Hui, C. Longcope, and C. C. Johnston. 1987. Sex steroids and bone mass: a study of changes about the time of menopause. J. Clin. Invest. 80:261-1269.

4. Lindsay, R., D. M. Hart, C. Forrest, and C. Baird. 1980. Prevention of spinal osteoporosis in oophorectomized women. Lancet. 2:1151-1154.

5. Raisz, L. G. 1988. Local and systemic factors in the pathogenesis of osteoporosis. N. Engl. J. Med. 318:818-828.

6. Dinarello, C. A. 1991. Interleukin-1 and Interleukin-1 antagonism. Blood. 777:1627-1652.

7. Smith, K. A., L. B. Lachman, J. J. Oppenheim, and M. F. Favata. 1980. The functional relationships of the interleukins. J. Exp. Med. 151:1551-1556.

8. Dinarello, C. A. 1984. Interleukin-1. Rev. Infect. Dis. 6:51-95.

9. Gowen, M., D. D. Wood, E. J. Ihrie, M. K. B. McGuire, and R. G. G. Russell. 1983. An interleukin-1-like factor stimulates bone resorption in vitro. Nature (Lond.). 306:378-380.

10. Lorenzo, J. A., S. L. Sousa, C. Alander, L. G. Raisz, and C. A. Dinarello. 1987. Comparison of the bone-resorbing activity in the supernatants from phytohemaglutinin-stimulated human peripheral blood mononuclear cells with that of cytokines through the use of an antiserum to interleukin 1. Endocrinology. 121:1164-1170.

11. Boyce, B. F., T. B. Aufdemorte, I. R. Garrett, A. J. P. Yates, and G. R. Mundy. 1989. Effects of interleukin-1 on bone turnover in normal mice. Endocrinology. 125:1142-1150.

12. Konig, A., R. C. Muhlbauer, and H. Fleisch. 1988. Tumor necrosis factor $\alpha$ and interleukin-1 stimulate bone resorption in vivo as measured by urinary $\left({ }^{3} \mathrm{H}\right)$ tetracycline excretion from prelabeled mice. J. Bone Miner. Res. 3:621-627.

13. Sabatini, M., B. Boyce, T. Aufdemorte, L. Bonewald, and G. R. Mundy. 1988. Infusions of recombinant human interleukin 1 alpha and beta cause hypercalcemia in normal mice. Proc. Natl. Acad. Sci. USA. 85:5235-5239.

14. Gowen, M., and G. R. Mundy. 1986. Actions of interleukin-1, interleukin-2, and interferon $\gamma$ on bone resorption in vitro. J. Immunol. 136:2478-2482.

15. Pfeilschifter, J., C. Chenu, A. Bird, G. R. Mundy, and G. D. Roodman. 1989. Interleukin-1 and tumor necrosis factor stimulate the formation of human osteoclast-like cells in vitro. J. Bone Miner. Res. 4:113-118.

16. Stashenko, P., F. E. Dewhirst, M. L. Rooney, L. A. Desjardins, and J. D. Heeley. 1987. Interleukin- $\beta$ is a potent inhibitor of bone formation in vitro. $J$. Bone Miner. Res. 2:559-565.

17. Nguyen, L., F. E. Dewhirst, P. V. Hauschka, and P. Stashenko. 1991. Interleukin- $1 \beta$ stimulates bone resorption and inhibits bone formation in vivo. Lymphokine Cytokine Res. 10:15-21.

18. Jilka, R. L., G. Hangoc, G. Girasole, G. Passeri, D. C. Williams, J. S. Abrams, B. Boyce, H. Broxmeyer, and S. C. Manolagas. 1992. Increased osteoclast development after estrogen loss: mediation by Interleukin-6. Science (Wash. DC). 257:88-91.

19. Felix, R., H. Fleish, and P. R. Elford. 1989. Bone-resorbing cytokines enhance release of macrophage colony-stimulating activity by osteoblastic cell MC3T3-E1. Calcif. Tissue Int. 44:356-360.

20. Ralston, S. H., S. A. Lusk, S. J. Gallagher, and I. T. Boyle. 1992. Evidence for enhanced cytokine gene expression in osteoporosis: analysis by mRNA phenotyping using the polymerase chain reaction. Calcif. Tissue Int. 7:A156.

21. Pacifici, R., L. Rifas, R. McCracken, I. Vered, C. McMurtry, L. V. Avioli, and W. A. Peck. 1989. Ovarian steroid treatment blocks a postmenopausal increase in blood monocyte interleukin 1 release. Proc. Natl. Acad. Sci. USA. 86:2398-2402.

22. Pacifici, R., C. Brown, E. Puscheck, E. Friedrich, E. Slatopolsky, D. Maggio, R. McCracken, and L. V. Avioli. 1991. Effect of surgical menopause and estrogen replacement on cytokine release from human blood mononuclear cells. Proc. Natl. Acad. Sci. USA. 88:5134-5138.

23. Pioli, G., G. Basini, M. Pedrazzoni, G. Musetti, V. Ulietti, D. Bresciani, P. Villa, A. Bacci, D. Hughes, G. Russell, and M. Passeri. 1992. Spontaneous release of Interleukin- 1 and interleukin- 6 by peripheral blood monocytes after ovariectomy. Clin. Sci. 83:503-507.

24. Matsuda, T., K. Matsui, Y. Shimakoshi, Y. Aida, and S. Hukuda. 1991. 1-Hydroxyethilidene-1, 1-bisphosphonate decreases the postovariectomy-enhanced interleukin 1 production by peritoneal macrophages in adult rats. Calcif. Tissue Int. 49:403-406. 
25. Ralston, S. H., R. G. G. Russell, and M. Gowen. 1990. Estrogen inhibits release of tumor necrosis factor from peripheral blood mononuclear cells in postmenopausal women. J. Bone Miner. Res. 5:983-988.

26. Girasole, G., R. L. Jilka, G. Passeri, S. Boswell, G. Boder, D. C. Williams, and S. C. Manolagas. 1992. 17 $\beta$-estradiol inhibits interleukin-6 production by bone marrow-derived stromal cells and osteoblasts in vitro: A potential mechanism for the antiosteoporotic effect of estrogens. J. Clin. Invest. 89:883-891.

27. Hannum, C. H., C. J. Wilcox, W. P. Arend, F. G. Joslin, D. J. Dripps, P. L. Heimdal, L. G. Armes, A. Sommer, S. P. Eisenberg, and R. C. Thompson. 1990 Interleukin-1 receptor antagonist activity of a human interleukin-1 inhibitor. Nature (Lond.). 343:336-340.

28. Carter, D. B., M. R. Deibel, Jr., C. J. Dunn, C-S. C. Tomich, A. L. Laborde, J. L. Slightom, A. E. Berger, M. J. Bienkowski, F. F. Sun, R. N. Mc Ewan, et al. 1990. Purification, cloning, expression and biological characterization of an interleukin-1 receptor antagonist protein. Nature (Lond.). 344:633638.

29. Arend, W. P., F. G. Joslin, R. C. Thompson, and C. H. Hannum. 1989. An IL-1 inhibitor from human monocytes. J. Immunol. 143:1851-1858.

30. Arend, W. P. 1991. Interleukin 1 receptor antagonist: A new member of the interleukin 1 family. J. Clin. Invest. 88:1445-1451.

31. Bluthe, R. M., R. Dantzer, and K. W. Kelley. 1992. Effects of interleukin1 receptor antagonist on the behavioral effects of lipopolysaccharide in rat. Brain Res. 573:318-320.

32. Zamir, O., M. D. Hasselgren, W. O'Brien, R. C. Thompson, and J. E. Fisher. 1992. Muscle protein breakdown during endotoxemia in rats and after treatment with interleukin-1 receptor antagonist (IL-1 ra). Ann. Surg. 216:381387.

33. Seckinger, P., J. Klein-Nulend, C. Alander, R. C. Thompson, J-M. Dayer, and L. G. Raisz. 1990. Natural and recombinant human IL-1 receptor antagonists block the effects of IL-1 on bone resorption and prostaglandin production. J. Immunol. 145:4181-4184.

34. Dinarello, C. A., and R. C. Thompson. 1991. Blocking IL-1: interleukin 1 receptor antagonist in vivo and in vitro. Immunol. Today. 12:404-410.

35. Griffin, M. G., R. Kimble, W. Hopfer, and R. Pacifici. 1993. Dual energy $\mathrm{X}$-ray absorptiometry (DEXA) of the rat: accuracy, precision and measurement of bone loss. J. Bone Miner. Res. 8:795-800.

36. Baron, R., A. Vignery, N. Lynn, A. Silverglate, and A. Santa Maria. 1983. Bone histomorphometry: techniques and interpretation. In Bone Histomorphometry: Techniques and Interpretation. R. R. Recker, editor. CRC Press, Boca Raton, FL. 13-35.

37. Turner, R. T., J. J. Vandersteenhoven, and N. Bell. 1987. The effects of ovariectomy and $17 \beta$-estradiol on cortical bone histomorphometry in growing rats. J. Bone Miner. Res. 2:115-122.

38. Frost, H. M. 1983. Bone Histomorphometry: Choice of Marking Agents and Labeling Schedule. R. R. Recker, editor. CRC Press, Boca Raton, FL. 37-52.

39. Uebelhart, D., E. Gineyts, M. C. Chapuy, and P. D. Delmas. 1990. Urinary excretion of pyridinium crosslinks: a new marker of bone resorption in metabolic bone disease. Bone Miner. 8:87-96.

40. Uebelhart, D., A. Schlemmer, J. S. Johansen, E. Gineyts, C. Christiansen, and P. D. Delmas. 1992. Effect of menopause and hormone replacement therapy on the urinary excretion of pyridinium crosslinks. J. Clin. Endocrinol. Metab. 72:367-373.

41. Seyedin, S. M., V. T. Kung, Y. N. Daniloff, R. P. Hesley, B. Gometz, L. A. Nielsen, H. N. Rosen, and R. F. Zuk. 1993. Immunoassay of urinary pyridinoline: the new marker of bone resorption. J. Bone Miner. Res. 8:635-641.

42. Delmas, P. D., E. Gineyts, A. Bertholin, P. Garnero, and F. Marchand. 1993. Immunoassay of pyridoline crosslink excretion in normal adults and in Paget's disease. J. Bone Miner. Res. 8:643-648.

43. Delmas, P. D. 1988. Biochemical markers of bone turnover in osteoporosis. In Osteoporosis. B. L. Riggs and L. J. Melton, editors. Raven Press, New York. 297-316.

44. Finkelman, R. D., T. A. Linkhart, S. Mohan, K. H. W. Lau, D. J. Baylink, and N. H. Bell. 1993. Vitamin D deficiency causes a selective reduction in deposition of TGF-beta in rat bone: possible mechanism for impaired osteoinduction. Proc. Natl. Acad. Sci. USA. 88:3657-3661.

45. Malyak, M., F. G. Joslin, E. P. Verderber, S. P. Eisenberg, and W. P. Arend. 1992. IL-1 ra ELISA: reduction and alkylation of synovial fluid eliminates interference by IgM rheumathoid factors. J. Immunol. Methods. 140:281-288.

46. Fuhlbrigge, R. C., D. D. Chaplin, J-M. Kiely, and E. R. Unanue. 1987. Regulation of interleukin 1 gene expression by adherence and lipopolysaccharide. J. Immunol. 138:3799-3802.

47. Dinarello, C. A. 1989. Interleukin-1 and its biologically related cytokines. Adv. Immunol. 44:153-205.

48. Wronski, T. J., C. C. Walsh, and L. A. Ignaszewski. 1986. Histologic evidence for osteopenia and increased bone turnover in ovariectomized rats. Bone. 7:119-123.

49. Arend, W. P., H. G. Welgus, R. C. Thompson, and S. P. Eisenberg. 1990 Biological properties of recombinant human monocyte-derived interleukin 1 receptor antagonist. J. Clin. Invest. 85:1694-1697.

50. Granowitz, E. V., R. Porat, J. W. Mier, J. P. Pribble, D. M. Stiles, D. C. Bloedow, M. A. Catalano, S. M. Wolff, and C. A. Dinarello. 1992. Pharmacokinetics, safety and immunomodulatory effects of human recombinant interleukin-1 receptor antagonist in healthy humans. Cytokine. 4:353-360.

51. Kalu, D. N., C. C. Liu, E. Salerno, B. Hollis, R. Echon, and M. Ray. 1991 Skeletal response of ovariectomized rats to low and high doses of $17 \beta$-estradiol. Bone Miner. 14:175-187.

52. Wronski, T. J., M. Cintron, A. L. Doherty, and L. M. Dann. 1988. Estrogen treatment prevents osteopenia and depresses bone turnover in ovariectomized rats. Endocrinology. 123:681-686.

53. Geusens, P., J. Dequeker, J. Nijs, and E. Bramm. 1990. Effect of ovariectomy and prednisolone on bone mineral content in rats: evaluation by single photon absorptiometry and radiogrammetry. Calcif. Tissue Int. 47:243-250.

54. Teitelbaum, S. L. 1993. Osteoporosis and the bone biopsy. In The Osteoporotic Syndrome: Detection, Prevention and Treatment. L. V. Avioli, editor. Wiley-Liss, New York. 63-76.

55. Podenphant, J., A. Gotfredsen, L. Nilas, H. Noorgard, and O. Braendstrup. 1986. Iliac crest biopsy: representativity for the amount of mineralized bone. Bone. 7:427-430.

56. Wronski, T. J., M. Cintron, and L. M. Dann. 1988. Temporal relationship between bone loss and increase bone turnover in ovariectomized rats. Calcif. Tissue Int. 43:179-183. 